\title{
Healthy Food on Instagram Social Network: Vegan, Homemade and Clean Eating
}

\author{
Ladislav Pilař $^{1, * \mathbb{D}}$, Lucie Kvasničková Stanislavská ${ }^{1} \mathbb{D}$, Roman Kvasnička $^{2} \mathbb{D}$, Richard Hartman ${ }^{1}$ \\ and Ivana Tichá ${ }^{1}$
}

Citation: Pilař, L.; Stanislavská, L.K.; Kvasnička, R.; Hartman, R.; Tichá, I. Healthy Food on Instagram Social Network: Vegan, Homemade and Clean Eating. Nutrients 2021, 13, 1991 https://doi.org/10.3390/nu13061991

Academic Editor: Dawn K. Wilson

Received: 15 April 2021

Accepted: 4 June 2021

Published: 9 June 2021

Publisher's Note: MDPI stays neutral with regard to jurisdictional claims in published maps and institutional affiliations.

Copyright: (c) 2021 by the authors. Licensee MDPI, Basel, Switzerland. This article is an open access article distributed under the terms and conditions of the Creative Commons Attribution (CC BY) license (https:// creativecommons.org/licenses/by/ $4.0 /)$.
1 Department of Management, Faculty of Economics and Management, Czech University of Life Sciences Prague, 16521 Prague, Czech Republic; kvasnickova@pef.czu.cz (L.K.S.); hartman@af.czu.cz (R.H.); ticha@pef.czu.cz (I.T.)

2 Department of Systems Engineering, Faculty of Economics and Management, Czech University of Life Sciences Prague, 16521 Prague, Czech Republic; kvasnicka@pef.czu.cz

* Correspondence: pilarl@pef.czu.cz; Tel.: +420-774-812-219

\begin{abstract}
Social media platforms have become part of many people's lives. Users are spending more and more time on these platforms, creating an active and passive digital footprint through their interaction. This footprint has high research potential in many research areas because understanding people's communication on social media is essential in understanding their values, attitudes, experiences and behaviors. Researchers found that the use of social networking sites impacts adolescents eating behavior. If we define adolescents as individuals between ages 10 and 24 (WHO's definition), $76 \%$ of USA young people at age 18-24 use Instagram, so the Instagram social network analysis is important for understanding young people's expressions in the context of healthy food. This study aims to identify the main topic associated with healthy food on the Instagram social network via hashtag and community analysis based on 2,045,653 messages created by 427,936 individual users. The results show that users most associate Healthy food with healthy lifestyle, fitness, weight loss and diet. In terms of food, these are foods that are Vegan, Homemade, Clean and Plant-based. Given that young people change their behavior in relation to people's behavior on social networks, it is possible to use this data to predict their future association with healthy food characteristics.
\end{abstract}

Keywords: healthy food; vegan; homemade food; clean eating; social media analysis; instagram

\section{Introduction}

Social media use is an inherent element of the lives of many people's lives, particularly for adolescents [1-3]. On average, adolescents spend $3.2 \mathrm{~h}$ per day on social media [4]. Social networks have become part of their lives, mainly thanks to the ability to create and share their creativity [5], experience and opinion [6], personal attitudes [7] and value [8].

Social media have a significant influence on adolescents in many areas of everyday life. This is a highly important and hot topic, which has been dealt with by many studies, for example: In fashion [9], beauty [10], mental health [11-14], health behaviors [15], alcohol consumption [16], sexual behavior [17], young people's health and well-being [15,18], as well as the influence of social media on eating behavior and lifestyle [19].

Understanding the factors that influence food selection is fundamental to support the successful translation of dietary goals into consumer behavior $[20,21]$. Since the social network Instagram is used by 76\% of USA young people at age between 18 and 24 [22], social media is an important source of information for understanding consumer behavior related to food behavior [23] through social media analysis, which identifies experience, values and attitudes [24-27] that users express through social networks. This information can be used both in the area of strategic management and business marketing $[7,28]$ and healthy policy [8]. 
Thus, providing another area of information that is important for understanding the complex issues of adolescent diet.

This study aims to identify the main topic associated with healthy food on the Instagram social network based on hashtag and community analysis.

The study further aims to answer the following research questions:

What areas do Instagram social network users emphasize through hashtags in the area of healthy food?

What communities exist on the Instagram social network in the area of healthy food?

\subsection{Theoretical Background}

Social media, such as Instagram, changed the way many people consume food [29]. Photos of food are used on Instagram in photographic exchanges to identify and interact with the community [29] and are the second most popular Instagram topic after selfies [30]. Popular social media users called influencers have a strong impact on their followers' decision-making [10,31-33]. In the field of healthy food, they replace the already established food personalities and celebrity chefs and become the creators of healthy eating rules [34] and informal sources of health education [35]. Influencers increasingly change the behavior of individuals in connection with food choice and diet and thus play a crucial role in public health [36].

Because social networks have become an integral part of the lives of many people, as well as food, which is an integral part of everyday life, mauch research is directed towards this area, which also focuses on the influence of social media on the eating habits of adolescents. Research Serenko et al. [3] found the negative influence of daily use of social media by adolescents on their eating habits, namely the habits of eating unhealthy foods. Unhealthy eating is also influenced by the negative influence of social media on the perception of their own body and self in young women [37], because they often support the unhealthy ideal of a very slim body [15]. On the other hand, social media expands the selection of healthy foods by creating an approach to various recipes $[38,39]$ or provide information on diets that can help solve obesity problems [40]. Blundell [19] also claims that social media can turn food preferences into healthier foods.

The exposed area of research is the impact of social media on the health of adolescents, most often focused on mental health [12,41,42]. These studies have shown inconsistent conclusions regarding the influence of social media use on the mental health of adolescents. Some studies draw attention to negative effects, such as the study of Barry et al. [43] that confirmed the correlation between the number of social media accounts and anxiety and depressive symptoms, hyperactivity/impulsivity, anxiety and fear of missing out in adolescents. Nereim et al. [44] draws attention to a stronger combination of passive use of social media with depression than active use (creating contributions) in adolescents. A greater amount of time spent on social media in adolescents is associated with an increased risk of self-harm [45] and depression [41,45-49], whilst lower levels of self-respect [41,45,46] with online harassment [41], bad sleep [3,41,46,50], higher levels of anxiety [46] and poor image of one's own body $[41,51,52]$. On the other hand, other studies have not found evidence to confirm the effect of social media on the deterioration of the mental state of adolescents [2,53-55]. Social networks cannot be viewed so unilaterally as platforms that only have a negative impact on adolescents. An example is the study Weinstein et al. [56], which identified the positive influence of social media on the mental state of adolescents, such as social connection, social support, affect-enhancing content, shared interests and resources for mental health and coping. Mental health, dietary patterns and many other aspects of adolescent life are highly interrelated areas affected by using social networks in both positive and negative contexts. Due to the fact that online social networks are still a new phenomenon, research of both a quantitative and qualitative character needs to be focused on individual aspects of human life in order to understand these platforms. 


\subsubsection{Social Media and Social Networks}

The terms social networks and social media are often confused with each other. However, there are several differences between them.

\subsubsection{Social Media}

Authors of The SAGE Handbook of Social Media Research Methods compared various definition of "social media" [57-61]. Individuals, groups, and organizations may use social media to collaborate, communicate, interact, and build community by allowing them to develop, co-create, modify, share, and engage with easily accessible user-generated content [62].

While some definitions stop short of specifying the type of content available, those that do specify content all agree that it is user- or consumer-generated. All definitions indicate what social media does; namely, it allows individuals, communities, and organizations to interact with one another by providing a service that enables them to communicate and collaborate and to create, modify, and share content. The definitions also concur that interactions occur through computer-mediated, web-based services [62]. Social media differ from traditional broadcast media because they directly support or create social networks using information and communication technologies [57].

\subsubsection{Social Networks}

John Barnes introduced the term "Social network" in 1954 [63]. In defining social networks, we start with view by Tichý: A social network is a particular collection of connections between a given group of people, with the added property that the characteristics of these connections as a whole can be used to interpret the social actions of the individuals involved [64]. Social networks portray the relationships that connect us as individuals to our families, communities, organizations, and societies [65]. Individuals, groups, organizations, and related structures form nodes in social networks linked by one or more forms of interdependencies. These interdependencies include, among other things, common beliefs, visions, and ideas; social contacts; kinship; conflict; financial exchanges; trade; joint membership in organizations; and community involvement in events [66]. Furthermore, the social network approach identifies organizations in society as a network of objects (e.g., individuals, groups, organizations) linked by various relationships. Not all pairs of objects are connected explicitly, and several relationships join others. The structure and patterning of these relationships focus on network analysis, defining both their causes and consequences [64]. Social networks are a broad concept that encompasses a wide range of types and functions, with each node having a unique relative value. Nodes are often used to describe events, ideas, or objects [66]. Any series of connections among a group of people and items form a social network. Social network science is a relatively young field, with origins in the early twentieth century pushed forward by scholars including Georg Simmel, Jacob Moreno, or Linton Freeman [67].

Generally, the main differences between online social media and online social network is as follows: social media is defined as a platform where people can share content through not only the social network they created, but also among other users of the platform. To make social media attractive to users, they allow them to create their own social network between people and groups, where they then communicate.

It is a relationship based on friendship or a certain interest.

\subsubsection{Social Media Analysis}

Social media analysis aims to collect, monitor, analyze, summarize and visualize data from social media platforms, from which valuable patterns and information can be identified [68]. Social Media Analytics is a new interdisciplinary research field that seeks to combine, expand, and adapt approaches for social media data analysis [69]. These basic methods include: Content Analysis, Sentiment Analysis and Opinion Analysis. Content analysis of social media photographs can be used for example for Landscape 
characterization [70] and Cultural ecosystem service usage [71]. Social media data can help with disaster management [72], detecting traffic accidents [73]. Sentiment analysis in social media analysis allows monitoring social media users opinions about selected products or services or identifying reputations in the context of their competitors and providing them with insight into emerging trends and potential changes in market opinions [74].

For example: Social media sentiment analysis based on COVID-19 [75]. Opinion analysis of social media data can tell us about public's opinions [76]. What opinions do the users hold? What is the size of each opinion group [77]?

\subsubsection{Social Network Analysis}

The study of patterns of relationships between individuals and groups such as organizations and states is the subject of social network analysis, a research technique developed primarily in sociology and communication science. The web can host social networks because it connects people and organizations [78]. The application of network science to the study of human relationships and interactions is known as social network analysis [67].

Social network analysis is a collection of mathematical and analytical methods used to explain the structure and dynamics of natural or artificial networks using network and graph theories [79]. Social network research lies at the crossroads of many disciplines. It's been linked to sociology, psychology, mathematics, anthropology, and network science for a long time [80]. The actors and their relationships in a particular social context are the two key focuses of social network research, aiming to understand networks and their users. The emphasis on the structure of relationships, ranging from casual acquaintance to close ties, is a distinguishing feature of social network research [66].

Metrics for social networks provide a specific perspective on patterns of knowledge flow and attention giving and receiving. At various levels of research, it provides context for defining key users and their potential impact. Units of analysis for social media network analysis vary and may include a node, a connection, a cluster, or the entire network [81].

Graph density, diameter, reciprocated vertex pair ratio, and a number of linked components are examples of aggregate network metrics that define the network as a whole. They also include network vertex metrics including degree, in-degree, out-degree, betweenness centrality, eigenvector centrality, closeness centrality, PageRank, and clustering coefficient, which can be used to find unique or significant people in a network [82].

Generally, the main differences between social network analysis and social media analysis are: The goal of analyzing social networks is to identify relationships and the strength of these relationships between individual objects in the network. The purpose of the analysis of social media is to analyze the content of communication between these objects.

\section{Materials and Methods}

The data analysis was based on the SMAHR framework [83]. SMAHR is a framework that is focused on Social media analysis based on hashtag research. The hashtag is a specific part of the message that begins with a "\#" character. On social media, the hashtag has two primary functions: filter posts, where the algorithms of social networks display an archive of messages related to this hashtag (topic) based on a specific hashtag [84], and the second function of hashtags is the way how to emphasize values, experience, attitudes and opinions in the message [24-27]. In the case of a healthy food, it can emphasize the properties of Gluten-Free, through the hashtag \#glutenfree. Gluten-Free is a property of food that may not be obvious from the text and photography. This framework has been already used in research focusing on organic foods [7], farmers' markets [28], sustainability [85], corporate social responsibility [86] and gamification [87]. The data analysis process based on SMAHR framework consisted of five steps (see Figure 2):

1. Data acquisition: Instagram social network was used for data. Instagram Scraper (https:/ / github.com/rarcega/instagram-scraper, accessed on 15 March 2021) was used to obtain data. The software extracted messages that used the hashtag \#healthyfood. The extracted data contained 2,045,653 messages created by 427,936 individual 
users. First, the user ID was encoded by random number algorithm so that it could not be converted back to a user ID. This information was used only to identify the number of users and is in no way associated with the downloaded hashtags. Subsequently, hashtags were extracted from the text of message into a separate database.

2. Content transformation: All letters were transformed into lower-case letters to prevent potential duplicates (e.g., the software might consider \#Organic, \#organic, and \#ORGANIC as three different hashtags). The dataset was imported into Gephi 0.9.2 software via the default import module. Hashtag network was created based on hashtag interdependence (see Figure 1). Gephi is a leading visualization and exploration open-source software for graphs and networks [88]. To use social network analysis methods, it was necessary to create a network of hashtags based on the rule: Nodes $=$ Hashtags and Edges $=$ their representation in one message.

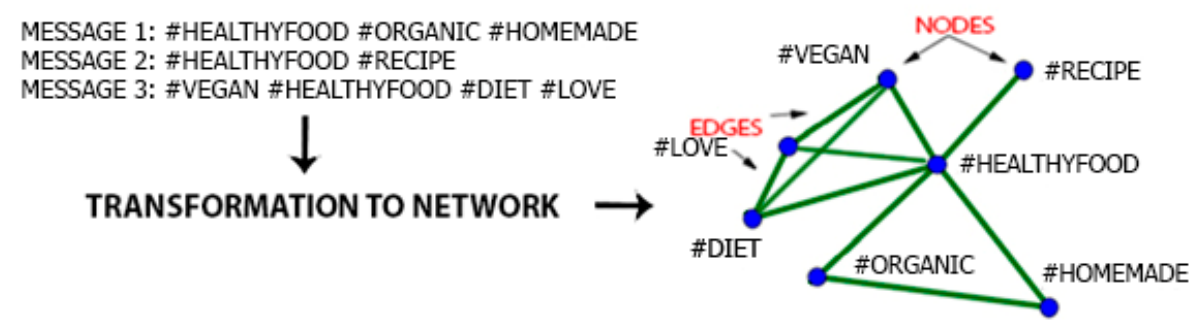

Figure 1. Transformation from the Instagram social network into a hashtag network.

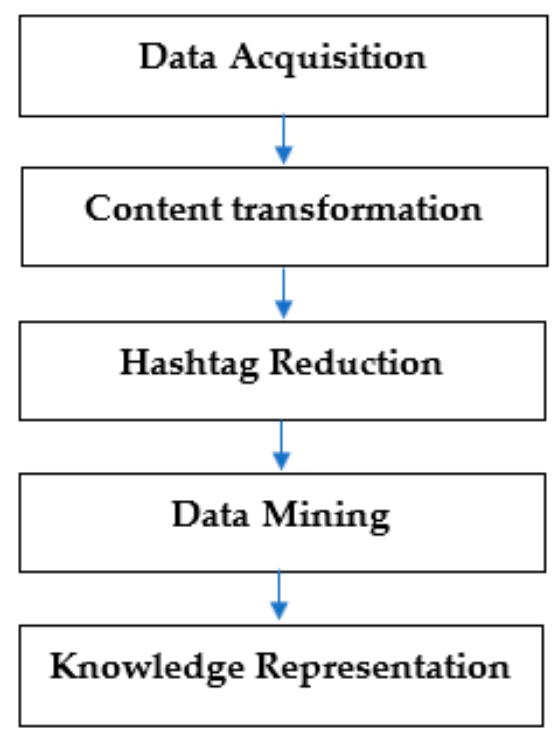

Figure 2. Five phases of social media analysis based on hashtag research (SMAHR) framework process.

For example:

Message: "I love this recipe \#healthyfood \#homemade \#organic" 3 Nodes (\#healthyfood, \#homemade and \#organic) are inserted into the graph and edges are created between these hashtags (because they are all in one message) see Figure 1. If the following message contains the text: "These brownies are amazing, if you want it, here is my \#healthyfood \#recipe for you", the hashtag \#recipe will be inserted into the graph, which will be connected only with the hashtag \#healthyfood, which already in the chart exists from the last message. For the \#healthyfood hashtag, the frequency value changes (increase) from 1 to 2 .

3. Hashtag reduction: Before using the community and modularity analysis, process a hashtag reduction that removes micro-communities. Many micro-communities are caused by an extensive number of hashtags that contain local hashtags, for example, a 
bakery in the Czech Republic—Prague Motol— \#bakerypraguemotol \#croissantfrombakerypraguemotol or hashtags created by the users themselves \#surnameandname.

4. Data mining: The following methods were used to describe the hashtag network:

(a) Frequency: The frequency is a value that expresses the hashtag frequency within a network.

(b) Eigenvector centrality: This is an extension of degree centrality, which measures the influence of hashtags in a network. Eigenvector centrality is calculated based on the premise that connections to hashtags with high values of degree centrality values have a significant influence than links with hashtags of similar or lower values of degree centrality values. A high eigenvector centrality value means that a hashtag is connected to many hashtags with a high degree centrality value. Eigenvector centrality was calculated as follows:

$$
x_{v}=\frac{1}{\lambda} \sum_{t \in M(v)} x_{t}=\frac{1}{\lambda} \sum_{t \in G} a_{v, t} x_{t}
$$

where $M(v)$ denotes a set of adjacent nodes and $\lambda$ is the largest eigenvalue. Eigenvector $x$ can be expressed by Equation (2):

$$
A x=\lambda x .
$$

(c) Betweenness Centrality: The value of Betweenness Centrality is highest for a hashtag if the paths between any two hashtags in the network always pass through this hashtag. Hashtags with a high degree of Betweenness Centrality can be referred to as network bottlenecks [89]. These hashtags are important in the network because they act as interconnectors or otherwise as bridges between remote parts of the network. The value of the Betweenness Centrality for the hashtag $\mathrm{v}$ in the graph $\mathrm{G}=(V, E)$ is calculated using the following relation:

$$
C_{B}(v)=\sum_{s \neq v \neq t \in V} \frac{\sigma_{s t}(v)}{\sigma_{s t}}
$$

(d) Community analysis and modularity: The most complex networks contain hashtags that are mutually interconnected to a more significant extent than they are connected to the rest of the network. Cluster of such hashtags are called communities [90]. Modularity represents an index that identifies the cohesion of communities within a given network [91]. The purpose is to identify hashtags communities that are mutually interconnected to a greater degree than other hashtags. Networks with high modularity show strong links between hashtags inside the community and weaker links between hashtags in other communities [92]. The community analysis then identifies the number of different community in the network based on the modularity detection analysis [93], as follows:

$$
\Delta Q=\left[\frac{\sum_{i n}+2 k_{i, i n}}{2 m}-\left(\frac{\sum_{t o t}+k_{i}}{2 m}\right)^{2}\right]-\left[\frac{\sum_{i n}}{2 m}-\left(\frac{\sum_{t o t}}{2 m}\right)^{2}\right],
$$

where $\sum_{i n}$ is the sum of weighted links inside the community, $\sum_{\text {tot }}$ is the sum of weighted links incident to hashtags in the community, $k_{i}$ is the sum of weighted links incident to hashtag $i, k_{i, i n}$ is the sum of weighted links going from $i$ to hashtags in the community, and $m$ is the normalizing factor as the sum of weighted links for the whole graph.

(e) Visualization of the network: Network visualization aims to identify individual communities and their mutual position. After importing the data into the Gephi program, the network's visualization is concentrated in the ba- 
sic square without visualizing the different relationships between individual hashtags. This visualization is unsatisfactory in identifying communities and their mutual positions but does not affect the analysis of hashtag-level and network-wide characteristics. In the field of visualization, it is possible to use the ForceAtlas2 algorithm. ForceAtlas2 is an improved version of the ForceAtlas algorithm, which focuses on large networks. This method is based on reduced samples' visual representation to define network communities and their types [94]. The advantage over ForceAtlas is its speed and ease of computing. The ideal number of hashtags is 10,000-100,000 [95].

5. Knowledge representation - a procedure that uses visualization tools to represent the results of data mining. Knowledge representation is based on the synthesis of individual values and outputs from the data evaluation phase.

\section{Results and Discussion}

First, analysis of the occurrence of individual hashtags in relation to Healthy food was used (See Table 1). For the extended version (80 hashtags), see Appendix A.

Table 1. Hashtags published in connection with the hashtag \#healthyfood on Instagram social Network.

\begin{tabular}{cccccc}
\hline No. & Hashtag & Fr & No. & Hashtag & Fr \\
\hline 1 & \#healthyfood & $2,455,746$ & 21 & \#plantbased * & 141,981 \\
2 & \#healthylifestyle & 938,430 & 22 & \#healthyrecipes & 141,165 \\
3 & \#fitness & 387,684 & 23 & \#gym & 139,368 \\
4 & \#weightloss & 317,019 & 24 & \#workout & 135,423 \\
5 & \#vegan * & 306,533 & 25 & \#slimmingworld & 132,084 \\
6 & \#homemade * & 304,428 & 26 & \#glutenfree* & 109,932 \\
7 & \#diet * & 253,830 & 27 & \#keto & 99,309 \\
8 & \#nutrition & 247,698 & 28 & \#restaurant & 98,934 \\
9 & \#dinner & 247,485 & 29 & \#fitfam & 94,002 \\
10 & \#healthyliving & 240,522 & 30 & \#organic & 93,807 \\
11 & \#weightlossjourney & 233,076 & 31 & \#lowcarb & 89,631 \\
12 & \#lunch & 232,473 & 32 & \#healthylife & 83,016 \\
13 & \#breakfast & 220,212 & 33 & \#wellness & 80,529 \\
14 & \#cooking & 210,120 & 34 & \#homecooking & 80,334 \\
15 & \#fit & 204,525 & 35 & \#slimmingworlduk & 77,448 \\
16 & \#motivation & 189,900 & 36 & \#bodybuilding & 77,145 \\
17 & \#eatclean * & 173,729 & 37 & \#weightlosstransformation & 74,259 \\
18 & \#fitnessmotivation & 162,123 & 38 & \#healthybreakfast & 72,708 \\
19 & \#vegetarian * & 144,513 & 39 & \#protein & 70,788 \\
20 & \#lifestyle & 143,058 & 40 & \#chef & 70,644 \\
\hline
\end{tabular}

${ }^{*}$ Linked with food, e.g., \# vegan * = \# vegan and \#veganfood (if both hashtags were in one message, it is counted only once); $\mathrm{Fr}=$ Frequency of Hashtag.

Based on the analysis of Healthy food through hashtag \#healthyfood, it is possible to identify Healthy Lifestyle (through hashtag \#healthylifestyle) as the most interconnected area. This is the confirmation of research that confirms the connection of lifestyle and choosing of healthy food $[8,32,96]$. The $3 \mathrm{rd}$ and 4 th places can identify two Fitness activities (through hashtag \#fitness) and Weight loss (through hashtag \#weightloss). This is the link between Healthy food and activities that aim to reduce weight. Based on community analysis (see Table 2), it is the largest community to be extracted in Healthy food. 
Table 2. Communities extracted from the reduced network.

\begin{tabular}{|c|c|c|c|}
\hline $\begin{array}{l}\text { Number of } \\
\text { Communities * }\end{array}$ & $\begin{array}{l}\text { Size of } \\
\text { Community }\end{array}$ & $\begin{array}{l}\text { Name of } \\
\text { Community }\end{array}$ & Key Hashtags \\
\hline 2 & $60.60 \%$ & $\begin{array}{l}\text { Active Healthy } \\
\text { lifestyle }\end{array}$ & $\begin{array}{c}\text { \#healthylifestyle, \#healthy, \#healthyeating, \#fitness, \#weightloss, } \\
\text { \#health, \#diet, \#weightlossjourney, \#fit, \#fitnessmotivation }\end{array}$ \\
\hline 0 & $24.63 \%$ & $\begin{array}{l}\text { Healthy food } \\
\text { bloggers }\end{array}$ & $\begin{array}{c}\text { \#food, \#foodie, \#foodporn, \#instafood, \#foodphotograph, y, \#yummy, } \\
\text { \#foodstagram\#foodblogger\#foodlover\#delicious\#instagood\#home- } \\
\text { made\#love\#dinner\#lunch\#breakfast\#tasty\#bhfyp\#cooking\#foo- } \\
\text { dies\#foodgasm\#instagram\#photooftheday }\end{array}$ \\
\hline 1 & $10.99 \%$ & Diets & $\begin{array}{l}\text { \#vegan\#vegetarian\#veganfood\#glutenfree\#plantbased\#vegeta- } \\
\text { bles\#veggies\#organic\#veganrecipes\#veggie\#veganlife\#vegetarianfood } \\
\text { \#vegetarianrecipes\#natural\#superfood\#green\#veganuary\#dairyfr- } \\
\text { ee\#veganfoodshare\#vegansofig,\#wholefood }\end{array}$ \\
\hline 3 & $3.79 \%$ & Keto & $\begin{array}{c}\text { \#keto \#lowcarb \#ketodiet \#easyrecipes \#ketorecipes \#ketolifestyle } \\
\text { \#ketomeals \#ketofood \#ketolife \#intermittentfasting \#ketogenic } \\
\text { \#ketoweightloss \#ketosis\#lchf \#sugarfree }\end{array}$ \\
\hline
\end{tabular}

${ }^{*}$ Numbers are linked with Figure 3.

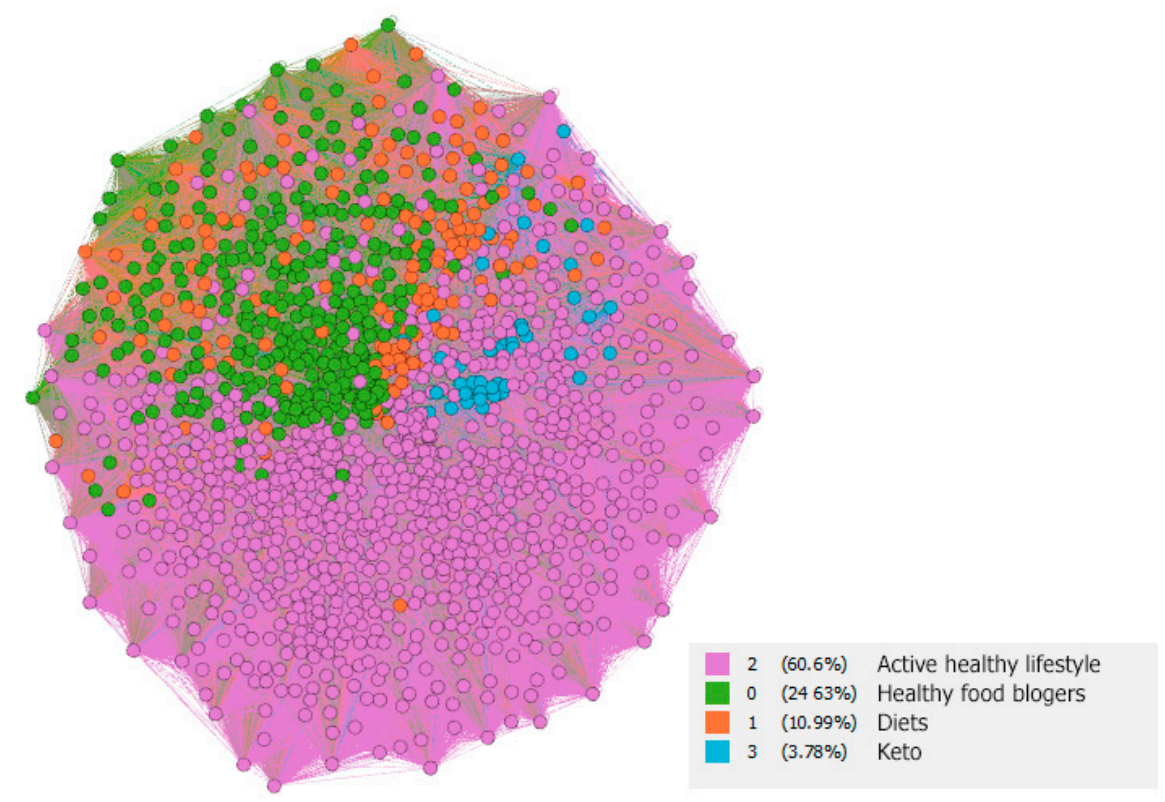

Figure 3. Community visualization in the area of healthy food on the Instagram social network.

The most common characteristics of healthy food on Instagram, which were identified by frequency analysis, are vegan (5th place), homemade (6th place), eat clean (17th place) and vegetarian (19th place).

In the 5 th place, the vegan area is most communicated (through hashtag \#vegan and \#veganfood). The vegan area was very often stigmatized and discouraged individuals from a plant-based diet [97-99]. The reason was that vegan and vegetarians disrupt social convention related to food [100-102]. At present, however, the vegan area is on the rise, both in terms of perception of customers and food producers who have experienced this rise and develop new vegan products, which they also consider one of the sustainability transition paths in the food sector [103]. These results confirm study [104] that showed that vegan and veganism are not a trend followed by a few people in western food culture, but a growing global trend. This also confirms [105], who identified veganism as a megatrend for 2019.

Next (6th) place is occupied by hashtag \#homemade, which means Homemade food. In Healthy food, Home food is associated with two basic areas. The first is focused on weight status [106] whilst the second on health balance. Following community analysis 
(see Table 2), home food on the social network is most widely used as a characteristic of food that is produced at home and popularized by healthy food bloggers. In other words, it is self-presentation on Instagram, where healthy food bloggers present their healthy food. Following the weight analysis, it was possible to characterize the 5 features mostly used in messages containing both hashtags (\#healthyfood and \#homemade), hashtags \#vegan, \#vegetarian, \#veganfood, \#plantbased and \#organic). As far as the type of food is concerned, it is mainly salad, then pasta and sweets. For more information, please see Annex 1. Based on the above, there is a strong link between food bloggers who promote homemade food and vegan and vegetarian lifestyle.

Another feature of healthy food on Instagram is clean food (17th place). In the last decade, clean eating has gained popularity as a dietary form (or approach) [107]. Despite this popularity, there is no single definition that defines exactly what the term "clean eating" means. It is generally seen as an approach to food that "promotes the exclusion of processed foods" [108], and is associated with eating "only whole and unprocessed food" [107]. The popularity of clean eating on social media is also confirmed by Ambwani et al. [109], which found that more than $50 \%$ of adolescents have knowledge of clean eating from social media or other online sources, and $72 \%$ perceive clean eating as a healthy way of eating. A study of [34] points out that significant "digital food Influencers" on social media create and share the meanings of good food which includes clean eating.

The community analysis extrapolated the following four communities: (1) Active Healthy lifestyle (2) Healthy food bloggers (3) Diets (4) Keto (see Table 2).

The largest community was the community focused on "Active Healthy lifestyle". Active Healthy lifestyle community contained hashtags that were associated with areas such as healthy lifestyle, fitness, fitness motivation, weight loss journey, healthy eating or fit. Health and weight control have become a necessary condition for wellbeing [35] in recent years. Weight reduction is a building block when dealing with obesity $[110,111]$, which is currently a global problem [112,113] and causes many health problems, such as metabolic diseases [114], cancer [115], higher risk of severe COVID-19 [116] or cardiovascular diseases [117]. The topics of this community, however, need not be related only to a healthy solution to obesity. It turns out that health content which promotes weight-management on social media may have unintended consequences, such as recurring weight loss and recovery cycles, chronic stress, avoidance of exercise and depression [35]. As many other studies $[37,118,119]$ have shown, there is a stronger correlation in adolescent girls between the use of social media and the concern about the image of their own body, which may result in eating problems such as pro-eating disorder [120-122].

The second-largest community was the "Healthy food bloggers" community, in which people shared foods they considered healthy. Healthy food bloggers community contained hashtags that were associated with areas such as foodporn, instafood, instablogger, delicious, etc. The high frequency of these hashtags (specifically delicious, yummy, foodie, foodporn) was also confirmed by the Muralidhara and Paul [123] study, which followed health topics on Instagram. Influencers on Instagram most often share recipes for food and nutritional advice online [36], idealizing healthy food style and creating a community feeling among their followers [29]. They often share not only instructions on how to cook healthy meals, but also how to prepare a perfect and proper lifestyle [34]. Hashtag \#foodporn is a phenomenon of recent years when social media users take pictures of meals before or when they are consumed and share them on social networks, especially Instagram [124,125]. The goal is to obtain social consent to shared food through likes, commenting and sharing [126-128].

The third community in terms of size is the "Diets" community, containing topics dealing with modern diet approaches such as vegan, vegetarian, gluten free, superfood, dairy free, whole food, etc. As we mentioned in the introduction, Influencer marketing plays a crucial role in public health [36], especially children and adolescents are very easy to influence by popular influencers on social media [33,129]. Popular influencers can motivate adolescents to a healthy diet [32], but many are not qualified nutritionists and 
their influence on adolescents may lead to health damage [36]. The popularity of 'free from' diets on Instagram is confirmed by Goodman and Jaworska [34]. These are often not diets within the meaning of health restrictions such as coeliac disease in gluten free diet, but a free decision for a healthy lifestyle $[130,131]$. However, the health benefits of these approaches are not often confirmed; on the contrary, there is evidence of possible damage involving possible nutritional deficiencies, financial costs and negative psychosocial consequences as a result of the exclusion of whole food categories [36,132]. With special dietary approaches, the phenomenon of over-focusing on a healthy lifestyle has already been given its professional name-orthorexia nervosa [133-135]. Research by Turner and Lefevre [136] revealed that among Instagram users who participated in their study, $49 \%$ of them met the criteria for orthoexia. No other social network has had this effect.

The smallest identified community is the "Keto" community. The community contains themes related to the so-called Ketogenic diets, such as low carb, keto recipes, keto lifestyle, keto weight loss, keto meals, etc. Ketogenic diet is a low-carbohydrate diet with high fat content, which results in the production of ketones by the liver and their uptake as an alternative energy source by the brain [137-139]. Although this dietary approach was previously used mainly to treat intractable epilepsy [140], it is currently being promoted as a strategy to combat obesity [141].

\subsection{Visual Analysis}

Based on a visual analysis where the low polarity of individual communities can be seen, which is confirmed by modularity $(0.265)$, it is possible to identify that the "Keto community" is in the middle of the "Active healthy lifestyle" community, while the "Diets community" is most in the area of "Healthy food bloggers" see Figure 3.

These results can be used mainly from the point of view of strategic marketing, where targeting the area of users who use the Keto diet is primarily in the field of active healthy lifestyle. This is confirmed by the value of betweenness centrality, which can be identified by community bridges (see Table 3), where after expected hashtags (\#healthy, \#healthyfood and \#healthy), the 4th place is taken by \#gym, 7th place by \#bodybuilding, 8th place by \#weightloss and 10th place by \#keto. These are the 4 hashtags working as an indicator of active healthy lifestyle, as a bridge between these communities. At the same time, it is possible to identify a very tight relationship between these communities (see Figure 4), where analysis is performed only for hashtags from the "Keto" and "Active healthy lifestyle" communities.

Table 3. Betweenes centrality (a) Active healthy lifestyle and Keto Community (b) Diets vs. Keto Communities.

\begin{tabular}{ccccc}
\hline & (a) Active Healthy Lifestyle and Keto Community & \multicolumn{2}{c}{ (b) Diets vs. Keto Communities } \\
Hashtag & Betweenes Centrality & Hashtag & Betweenes Centrality \\
\hline 1 & \#health & 0.00201 & \#veg & 0.00692 \\
2 & \#healthyfood & 0.00201 & \#vegan & 0.00374 \\
3 & \#healthy & 0.00177 & \#veganfood & 0.00353 \\
4 & \#gym & 0.00169 & \#glutenfree & 0.00346 \\
5 & \#healthyeating & 0.00156 & \#easyrecipes & 0.00341 \\
6 & \#healthylifestyle & 0.00156 & \#keto & 0.00337 \\
7 & \#bodybuilding & 0.00156 & \#cauliflower & 0.00332 \\
8 & \#weightloss & 0.00152 & \#veganrecipes & 0.00332 \\
9 & \#keto & 0.00152 & \#lowcarb & 0.00331 \\
10 & \#fitness & 0.00149 & \#goodfood & 0.00324 \\
\hline
\end{tabular}




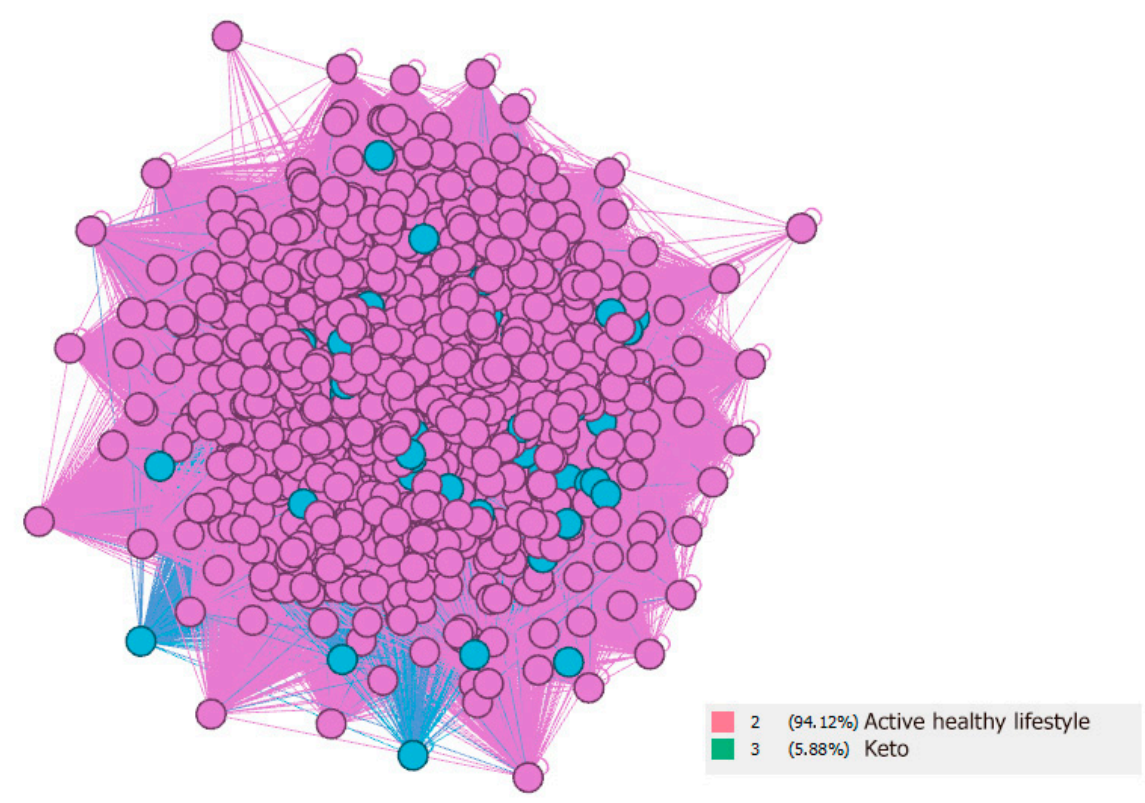

Figure 4. Active healthy lifestyle and Keto community visualization on the Instagram social network in the area of healthy food.

When analyzing the two minority communities "Diets" and "Keto", as indicated in Figure 5 and Table 3. it can be determined that this is a more polarized community where the "Diets" community does not interfere with the "Keto" community, but the "Keto" area is more associated with the "Diets" area. By identifying bridges through betweenness centrality, \#glutenfree can be identified as a bridge between these communities.

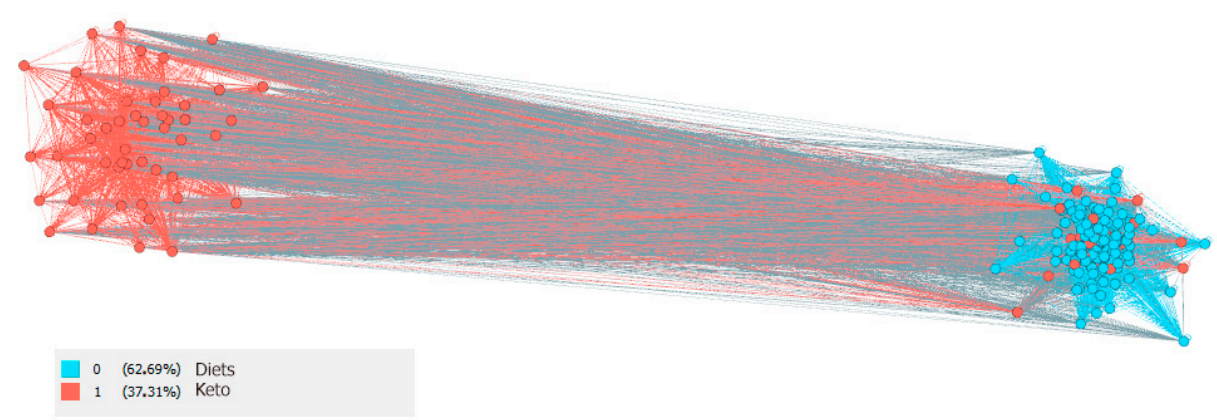

Figure 5. Keto and Diets community visualization on the Instagram social network in the area of healthy food.

\subsection{Limitation of Research}

Due to the growing trends in using social media platforms, a social media analysis has a high research potential, however, as another research method, some limitation of this study deserves attention.

First of all, this research was based on SMAHR (Social Media Analysis based on Hashtag Research) framework [83]. This framework specializes in the use of hashtags for social media analysis. Hashtags are a specific part of message communication where the user emphasizes experiences, personal attitudes or values. It is a method that focuses on areas that users specifically emphasize. The limit is that the analysis does not include messages that the topic contains, but the user does not use hashtags. According to the authors of the SMAHR framework [83], it is a competitive framework to other frameworks that focus on text or object identification in the attached image because it can identify areas that users do not express in the plain text of message or through the attached image.

Second, like other research based on social media analyses, this study focuses only on one social network $[7,23,28,85,87,142]$ and on English hashtags. 
Third, this study did not deal with the geolocation of sending messages. Unlike Twitter, Instagram API does not offer this feature.

Fourth, the study analyzes the current situation and does not deal with predictions for the future. Instagram does not offer the ability to download the date when the message was sent, which is important for predictions.

Sixth, this study does not claim the general perception of healthy food. This study identifies how is healthy food presented on the Instagram social network. For this reason, data includes only the opinions of people who use the Instagram social network, which cannot be applied to the entire population. However, this is essential information in understanding adolescents' food choices because social networks affect especially young people behavior, and the Instagram social network is used by $76 \%$ of USA young people at age 18-24.

\subsection{Future Research}

The results of this study opened many important questions for further research through both quantitative and qualitative methods.

The present research identified values, experience, attitudes and characteristics that Instagram users express in the healthy food area through hashtags.

In future research, it will be necessary to focus on the most frequent identified areas: healthy lifestyle, homemade, weight loss, vegan, clean eating, vegetarian, gluten-free and low carb (keto).

According to experts, some dietary approaches associated on Instagram with healthy food are not unequivocally evaluated as health-friendly (for example, the keto diet [143]). It will be necessary to verify the impact of the identified areas on human health in the future.

A significantly identified hashtag associated with healthy food is the hashtag \#weightloss. However, research [120-122] has confirmed a stronger correlation between social media use and pro-eating disorder in adolescent girls. The following research would be useful to find out the content of posts with the hashtag \#weightloss and their impact on health.

\section{Conclusions}

Based on an analysis of the Instagram social network, it is possible to say that users most associate healthy food with healthy lifestyle. From the point of view of hashtags that are directly drawn to food, the first three places in view of food characteristics are taken by: \#vegan, \#homemade and \#eatclean. Following the different concepts of this area, where diversity occurs, whether vegan is a diet or lifestyle, it has been observed that people on the Instagram social network express themselves on the concept of vegan as lifestyle characteristics.

Although individuals following a vegan lifestyle are a minority, research indicates a high link in healthy food communication in terms of both the \#vegan and \#veganfood hashtags usage frequency and extracting own community. Due to the fact that users selfcreate these characteristics on social networks, it is possible to believe that stigmatization of this area is declining and is an important trend in healthy living and healthy lifestyle.

Many studies have indicated that social networks affect the behavior of adolescents. Due to the fact that Instagram social network is part of the life of many adolescents (for example, $76 \%$ of USA young people at age 18-24 use Instagram), we can predict the tendency to Vegan, Homemade, Clean Eat, Plant-based, Gluten Free and Keto diet in these adolescents provided that they follow the healthy food topic.

Following the community analysis, it is possible to identify "Active healthy lifestyle" as the largest community, which confirms that people on the social network Instagram associate healthy food with an active, healthy lifestyle. The second-largest community is the Influencer Marketing community, meaning that the second-largest community seeks to influence other users in the field of food behaviors, confirming that social networks have the potential to influence people's behaviors in real life. The third community in terms of 
size is the "Diets" community, containing topics dealing with modern diet approaches such as vegan, vegetarian, gluten free, superfood, dairy free, whole food. The smallest identified community is the "Keto" community. It is currently a trendy diet, which is spreading on social networks. It is important to note here that this diet should not be used without consulting an expert. The identification of "Keto" community confirms the importance of social network analysis, as it is possible to identify a direction that can lead to health problems but is also associated with healthy food.

The results of this study opened many important questions for further research through both quantitative and qualitative methods.

These results can be used both in terms of practical use in the area of strategic management of the product portfolio and strategic marketing in terms of defining the value proposition of the product and in terms of theoretical benefits, where it is possible to identify the area of Vegan, Homemade and Clean Eating as areas that social media users associated with a healthy lifestyle.

Author Contributions: Writing—original draft preparation: L.P. and L.K.S.; conceptualization: L.P., L.K.S. and I.T.; methodology: L.P. and L.K.S.; validation: L.K.S. and R.H.; formal analysis: R.H., L.K.S. and L.P.; resources: L.P. and R.H.; data curation: R.H.; writing—review and editing: L.P., L.K.S., R.H., I.T. and R.K.; project administration: L.P., I.T. and R.K. All authors have read and agreed to the published version of the manuscript.

Funding: This study was supported by the Internal Grant Agency (IGA) of FEM CULS in Prague, registration no. 2020B0004-Use of artificial intelligence to predict communication on social networks.

Institutional Review Board Statement: Ethical review and approval are not required in this study because the information-gathering process focused on tweets and personal information were excluded via data collection. Username was coded to unique ID for identification of a number of users, but no identifiable private information was collected, following the ethical guidelines and definitions of "studies that are not human subjects research".

Informed Consent Statement: Ethical review and approval are not required in this study because the information-gathering process focused on Instagram and personal information were excluded via data collection. In the studies, the username was coded to a unique ID for the identification of a number of users, but no identifiable private information was collected, following the ethical guidelines and definitions of "studies that are not human subjects research".

Data Availability Statement: All data used in this study can be downloaded via the Instagram Scraper (see Data aqusition).

Conflicts of Interest: The authors declare no conflict of interest. The funder (FEM CULS in Prague) had no role in the design of the study; in the collection, analyses, or interpretation of the data; in the writing of the manuscript; or in the decision to publish the results.

\section{Appendix A}

Table A1. Hashtags published in connection with the hashtag \#healthyfood on Instagram social Network with non-relevant hashtags.

\begin{tabular}{cccccc}
\hline No & Hashtag & Notes & No & Hashtag & Notes \\
\hline 1 & \#healthyfood & & 41 & \#plantbased & \\
2 & \#healthylifestyle & & 42 & \#healthyrecipes & \\
3 & \#food & $*$ & 43 & \#gym & \\
4 & \#healthy & $*$ & 44 & \#workout & $*$ \\
5 & \#foodie & $*$ & 45 & \#photooftheday & \\
6 & \#foodporn & $*$ & 46 & \#eatclean & $*$ \\
7 & \#instafood & $*$ & 47 & \#picoftheday & \\
\hline
\end{tabular}


Table A1. Cont.

\begin{tabular}{|c|c|c|c|c|c|}
\hline No & Hashtag & Notes & No & Hashtag & Notes \\
\hline 8 & \#healthyeating & * & 48 & \#instadaily & * \\
\hline 9 & \#foodphotography & * & 49 & \#glutenfree & \\
\hline 10 & \#fitness & & 50 & \#cleaneating & \\
\hline 11 & \#yummy & * & 51 & \#follow & * \\
\hline 12 & \#foodstagram & * & 52 & \#keto & \\
\hline 13 & \#foodblogger & * & 53 & \#restaurant & \\
\hline 14 & \#foodlover & * & 54 & \#fitfam & \\
\hline 15 & \#delicious & * & 55 & \#organic & \\
\hline 16 & \#weightloss & & 56 & \#lowcarb & \\
\hline 17 & \#health & * & 57 & \#eat & * \\
\hline 18 & \#instagood & * & 58 & \#healthylife & \\
\hline 19 & \#homemade & & 59 & \#like & * \\
\hline 20 & \#vegan & & 60 & \#wellness & \\
\hline 21 & \#love & * & 61 & \#homecooking & \\
\hline 22 & \#nutrition & & 62 & \#foodiesofinstagram & * \\
\hline 23 & \#dinner & * & 63 & \#foodpics & * \\
\hline 24 & \#healthyliving & * & 64 & \#bodybuilding & \\
\hline 25 & \#diet & & 65 & \#weightlosstransformation & \\
\hline 26 & \#weightlossjourney & & 66 & \#exercise & \\
\hline 27 & \#lunch & * & 67 & \#foodblog & \\
\hline 28 & \#breakfast & * & 68 & \#healthybreakfast & \\
\hline 29 & \#tasty & * & 69 & \#protein & \\
\hline 30 & \#bhfyp & * & 70 & \#chef & \\
\hline 31 & \#cooking & & 71 & \#veganrecipes & \\
\hline 32 & \#fit & & 72 & \#weightlossmotivation & \\
\hline 33 & \#motivation & & 73 & \#salad & \\
\hline 34 & \#foodies & * & 74 & \#eathealthy & \\
\hline 35 & \#foodgasm & * & 75 & \#training & \\
\hline 36 & \#fitnessmotivation & & 76 & \#healthychoices & \\
\hline 37 & \#veganfood & & 77 & \#fitfood & \\
\hline 38 & \#vegetarian & & 78 & \#vegetables & \\
\hline 39 & \#lifestyle & & 79 & \#dieta & \\
\hline 40 & \#instagram & * & 80 & \#yum & \\
\hline
\end{tabular}

\section{References}

1. O'Day, E.B.; Heimberg, R.G. Social Media Use, Social Anxiety, and Loneliness: A Systematic Review. Comput. Hum. Behav. Rep. 2021, 3, 100070. [CrossRef]

2. Shafi, R.M.A.; Nakonezny, P.A.; Miller, K.A.; Desai, J.; Almorsy, A.G.; Ligezka, A.N.; Morath, B.A.; Romanowicz, M.; Croarkin, P.E. Altered Markers of Stress in Depressed Adolescents after Acute Social Media Use. J. Psychiatr. Res. 2021, 136, 149-156. [CrossRef] [PubMed]

3. Serenko, A.; Turel, O.; Bohonis, H. The Impact of Social Networking Sites Use on Health-Related Outcomes among UK Adolescents. Comput. Hum. Behav. Rep. 2021, 3, 100058. [CrossRef]

4. Tankovska, H. Daily Social Media Time among Teens and Young Adults Worldwide 2017. Available online: https://www.statista. com/statistics / 800821/average-daily-time-spent-social-media-teens-young-adults/ (accessed on 1 April 2021).

5. Longobardi, C.; Settanni, M.; Fabris, M.A.; Marengo, D. Follow or Be Followed: Exploring the Links between Instagram Popularity, Social Media Addiction, Cyber Victimization, and Subjective Happiness in Italian Adolescents. Child. Youth Serv. Rev. 2020, 113, 104955. [CrossRef]

6. Cho, M.; Furey, L.D.; Mohr, T. Communicating Corporate Social Responsibility on Social Media. Bus. Prof. Commun. Q. 2017, 80, 52-69. [CrossRef]

7. Pilař, L.; Kvasničková Stanislavská, L.; Poláková, J.; Rojík, S.; Kvasnička, R.; Gresham, G. Customer Experience with Organic Food: Global View. Emir. J. Food Agric. 2018, 30. [CrossRef]

8. Pilař, L.; Kvasničková Stanislavská, L.; Kvasnička, R. Healthy Food on the Twitter Social Network: Vegan, Homemade, and Organic Food. Int. J. Environ. Res. Public Health 2021, 18, 3815. [CrossRef]

9. Brambilla, M.; Javadian Sabet, A.; Hosseini, M. The Role of Social Media in Long-Running Live Events: The Case of the Big Four Fashion Weeks Dataset. Data Brief 2021, 35, 106840. [CrossRef] 
10. Mardon, R.; Molesworth, M.; Grigore, G. YouTube Beauty Gurus and the Emotional Labour of Tribal Entrepreneurship. J. Bus. Res. 2018, 92, 443-454. [CrossRef]

11. Jaini, P.A.; Hsu, J.; Manjunath, P.; Haliburton, J.R. 39.5 General psychiatry residents' attitudes toward discussing social media's influence on mental health with adolescent and young adult patients. J. Am. Acad. Child Adolesc. Psychiatry 2020, 59, S220. [CrossRef]

12. Keles, B.; McCrae, N.; Grealish, A. A Systematic Review: The Influence of Social Media on Depression, Anxiety and Psychological Distress in Adolescents. Int. J. Adolesc. Youth 2020, 25, 79-93. [CrossRef]

13. Berryman, C.; Ferguson, C.J.; Negy, C. Social Media Use and Mental Health among Young Adults. Psychiatr. Q. 2018, 89, 307-314. [CrossRef] [PubMed]

14. Ivie, E.J.; Pettitt, A.; Moses, L.J.; Allen, N.B. A Meta-Analysis of the Association between Adolescent Social Media Use and Depressive Symptoms. J. Affect. Disord. 2020, 275, 165-174. [CrossRef] [PubMed]

15. Moreno, M.A.; Standiford, M.; Cody, P. Social Media and Adolescent Health. Curr. Pediatr. Rep. 2018, 6, 132-138. [CrossRef]

16. Egan, K.G.; Moreno, M.A. Alcohol References on Undergraduate Males' Facebook Profiles. Am. J. Mens Health 2011, 5, 413-420. [CrossRef]

17. Romo, D.L.; Garnett, C.; Younger, A.P.; Soren, K.; Stockwell, M.S.; Catallozzi, M.; Neu, N. Understanding Adolescent Social Media Use: Association With Sexual Risk and Parental Monitoring Factors That Can Influence Protection. J. Adolesc. Health 2016, 58, S16-S17. [CrossRef]

18. Shafi, R.M.A.; Romanowicz, M.; Croarkin, P.E. \#SwitchedOn: A Call for Assessing Social Media Use of Adolescents. Lancet Psychiatry 2018, 5, e27. [CrossRef]

19. Blundell, K.-L.; Forwood, S. Using a Social Media App, Instagram, to Affect What Undergraduate University Students Choose to Eat. Appetite 2021, 157, 104887. [CrossRef]

20. Lassen, A.D.; Lehmann, C.; Andersen, E.W.; Werther, M.N.; Thorsen, A.V.; Trolle, E.; Gross, G.; Tetens, I. Gender Differences in Purchase Intentions and Reasons for Meal Selection among Fast Food Customers-Opportunities for Healthier and More Sustainable Fast Food. Food Qual. Prefer. 2016, 47, 123-129. [CrossRef]

21. Carrillo, E.; Varela, P.; Salvador, A.; Fiszman, S. MAIN FACTORS UNDERLYING CONSUMERS' FOOD CHOICE: A FIRST STEP FOR THE UNDERSTANDING OF ATTITUDES TOWARD “HEALTHY EATING.”. J. Sens. Stud. 2011, 26, 85-95. [CrossRef]

22. Auxier, B.; Anderson, M. Social Media Use in 2021. Available online: https://www.pewresearch.org/internet/2021/04/07 /social-media-use-in-2021/ (accessed on 1 April 2021).

23. Vidal, L.; Ares, G.; Machín, L.; Jaeger, S.R. Using Twitter Data for Food-Related Consumer Research: A Case Study on "What People Say When Tweeting about Different Eating Situations". Food Qual. Prefer. 2015, 45, 58-69. [CrossRef]

24. Pilař, L.; Poláková, J.; Gresham, G.; Rojík, S.; Tichá, I. Why people use hashtags when visiting farmers ' markets. In Proceedings of the Agrarian Perspectives XXVI: Competitiveness of European Agriculture and Food Sectors, Prague, Czech Republic, 13-15 September 2017.

25. Zhang, K.; Geng, Y.; Zhao, J.; Liu, J.; Li, W. Sentiment Analysis of Social Media via Multimodal Feature Fusion. Symmetry 2020, 12, 2010. [CrossRef]

26. Childers, C.C.; Lemon, L.L.; Hoy, M.G. \#Sponsored \#Ad: Agency Perspective on Influencer Marketing Campaigns. J. Curr. Issues Res. Advert. 2019, 40, 258-274. [CrossRef]

27. De Veirman, M.; Cauberghe, V.; Hudders, L. Marketing through Instagram Influencers: The Impact of Number of Followers and Product Divergence on Brand Attitude. Int. J. Advert. 2017, 36, 798-828. [CrossRef]

28. Pilař, L.; Balcarová, T.; Rojík, S.; Tichá, I.; Poláková, J. Customer Experience with Farmers' Markets: What Hashtags Can Reveal. Int. Food Agribus. Manag. Rev. 2018, 21, 755-770. [CrossRef]

29. Walsh, M.J.; Baker, S.A. Clean Eating and Instagram: Purity, Defilement, and the Idealization of Food. Food Cult. Soc. 2020, 23, 570-588. [CrossRef]

30. Amato, G.; Bolettieri, P.; Monteiro de Lira, V.; Muntean, C.I.; Perego, R.; Renso, C. Social Media Image Recognition for Food Trend Analysis. In Proceedings of the 40th International ACM SIGIR Conference on Research and Development in Information Retrieval, Tokyo, Japan, 7-11 August 2017; ACM: New York, NY, USA, 2017; pp. 1333-1336.

31. Hudders, L.; De Jans, S.; De Veirman, M. The Commercialization of Social Media Stars: A Literature Review and Conceptual Framework on the Strategic Use of Social Media Influencers. Int. J. Advert. 2020, 1-49. [CrossRef]

32. De Jans, S.; Spielvogel, I.; Naderer, B.; Hudders, L. Digital Food Marketing to Children: How an Influencer's Lifestyle Can Stimulate Healthy Food Choices among Children. Appetite 2021, 162, 105182. [CrossRef] [PubMed]

33. Coates, A.E.; Hardman, C.A.; Halford, J.C.G.; Christiansen, P.; Boyland, E.J. “It's Just Addictive People That Make Addictive Videos": Children's Understanding of and Attitudes towards Influencer Marketing of Food and Beverages by YouTube Video Bloggers. Int. J. Environ. Res. Public Health 2020, 17, 449. [CrossRef]

34. Goodman, M.K.; Jaworska, S. Mapping Digital Foodscapes: Digital Food Influencers and the Grammars of Good Food. Geoforum 2020, 117, 183-193. [CrossRef]

35. Marks, R.J.; De Foe, A.; Collett, J. The Pursuit of Wellness: Social Media, Body Image and Eating Disorders. Child. Youth Serv. Rev. 2020, 119, 105659. [CrossRef]

36. Byrne, E.; Kearney, J.; MacEvilly, C. The Role of Influencer Marketing and Social Influencers in Public Health. Proc. Nutr. Soc. 2017, 76, E103. [CrossRef] 
37. Perloff, R.M. Social Media Effects on Young Women's Body Image Concerns: Theoretical Perspectives and an Agenda for Research. Sex Roles 2014, 71, 363-377. [CrossRef]

38. Vaterlaus, J.M.; Patten, E.V.; Roche, C.; Young, J.A. \#Gettinghealthy: The Perceived Influence of Social Media on Young Adult Health Behaviors. Comput. Hum. Behav. 2015, 45, 151-157. [CrossRef]

39. Nelson, A.M.; Fleming, R. Gender Differences in Diet and Social Media: An Explorative Study. Appetite 2019, $142,104383$. [CrossRef]

40. Hawks, J.R.; Madanat, H.; Walsh-Buhi, E.R.; Hartman, S.; Nara, A.; Strong, D.; Anderson, C. Narrative Review of Social Media as a Research Tool for Diet and Weight Loss. Comput. Hum. Behav. 2020, 111, 106426. [CrossRef]

41. Kelly, Y.; Zilanawala, A.; Booker, C.; Sacker, A. Social Media Use and Adolescent Mental Health: Findings From the UK Millennium Cohort Study. EClinicalMedicine 2018, 6, 59-68. [CrossRef]

42. Argo, T.; Lowery, L. The Effects of Social Media on Adolescent Health and Well-Being. J. Adolesc. Health 2017, 60, S75-S76. [CrossRef]

43. Barry, C.T.; Sidoti, C.L.; Briggs, S.M.; Reiter, S.R.; Lindsey, R.A. Adolescent Social Media Use and Mental Health from Adolescent and Parent Perspectives. J. Adolesc. 2017, 61, 1-11. [CrossRef] [PubMed]

44. Nereim, C.D.; Bickham, D.S.; Rich, M.O. 234. Social Media and Adolescent Mental Health: Who You Are and What You Do Matter. J. Adolesc. Health 2020, 66, S118-S119. [CrossRef]

45. Barthorpe, A.; Winstone, L.; Mars, B.; Moran, P. Is Social Media Screen Time Really Associated with Poor Adolescent Mental Health? A Time Use Diary Study. J. Affect. Disord. 2020, 274, 864-870. [CrossRef]

46. Woods, H.C.; Scott, H. \#Sleepyteens: Social Media Use in Adolescence Is Associated with Poor Sleep Quality, Anxiety, Depression and Low Self-Esteem. J. Adolesc. 2016, 51, 41-49. [CrossRef] [PubMed]

47. McCrae, N.; Gettings, S.; Purssell, E. Social Media and Depressive Symptoms in Childhood and Adolescence: A Systematic Review. Adolesc. Res. Rev. 2017, 2, 315-330. [CrossRef]

48. Hoare, E.; Milton, K.; Foster, C.; Allender, S. The Associations between Sedentary Behaviour and Mental Health among Adolescents: A Systematic Review. Int. J. Behav. Nutr. Phys. Act. 2016, 13, 108. [CrossRef] [PubMed]

49. Raudsepp, L.; Kais, K. Longitudinal Associations between Problematic Social Media Use and Depressive Symptoms in Adolescent Girls. Prev. Med. Rep. 2019, 15, 100925. [CrossRef]

50. Khan, A.; Uddin, R.; Islam, S.M.S. Social Media Use Is Associated with Sleep Duration and Disturbance among Adolescents in Bangladesh. Health Policy Technol. 2019, 8, 313-315. [CrossRef]

51. Burnette, C.B.; Kwitowski, M.A.; Mazzeo, S.E. “I Don't Need People to Tell Me I'm Pretty on Social Media:" A Qualitative Study of Social Media and Body Image in Early Adolescent Girls. Body Image 2017, 23, 114-125. [CrossRef]

52. Jarman, H.K.; Marques, M.D.; McLean, S.A.; Slater, A.; Paxton, S.J. Social Media, Body Satisfaction and Well-Being among Adolescents: A Mediation Model of Appearance-Ideal Internalization and Comparison. Body Image 2021, 36, 139-148. [CrossRef] [PubMed]

53. Beeres, D.T.; Andersson, F.; Vossen, H.G.M.; Galanti, M.R. Social Media and Mental Health Among Early Adolescents in Sweden: A Longitudinal Study With 2-Year Follow-Up (KUPOL Study). J. Adolesc. Health 2020, 68. [CrossRef]

54. Kreski, N.; Platt, J.; Rutherford, C.; Olfson, M.; Odgers, C.; Schulenberg, J.; Keyes, K.M. Social Media Use and Depressive Symptoms Among United States Adolescents. J. Adolesc. Health 2021, 68, 572-579. [CrossRef] [PubMed]

55. Merrill, R.A.; Liang, X. Associations between Adolescent Media Use, Mental Health, and Risky Sexual Behaviors. Child. Youth Serv. Rev. 2019, 103, 1-9. [CrossRef]

56. Weinstein, E.; Kleiman, E.M.; Franz, P.J.; Joyce, V.W.; Nash, C.C.; Buonopane, R.J.; Nock, M.K. Positive and Negative Uses of Social Media among Adolescents Hospitalized for Suicidal Behavior. J. Adolesc. 2021, 87, 63-73. [CrossRef]

57. Kaplan, A.M.; Haenlein, M. Users of the World, Unite! The Challenges and Opportunities of Social Media. Bus. Horiz. 2010, 53, 59-68. [CrossRef]

58. Gruzd, A.; Staves, K.; Wilk, A. Connected Scholars: Examining the Role of Social Media in Research Practices of Faculty Using the UTAUT Model. Comput. Hum. Behav. 2012, 28, 2340-2350. [CrossRef]

59. Correa, T.; Hinsley, A.W.; de Zúñiga, H.G. Who Interacts on the Web?: The Intersection of Users' Personality and Social Media Use. Comput. Hum. Behav. 2010, 26, 247-253. [CrossRef]

60. Otieno, D.O.; Matoke, V.B. Social Media as Tool for Conducting Academic Research. Int. J. Adv. Res. Comput. Sci. Softw. Eng. 2014, 4, 962-967.

61. Tran, V.T.; Hue Do, H. An Impact of Social Media and Online Travel Information Search in Vietnam. J. Tour. Res. Hosp. 2016, 5. [CrossRef]

62. Sloan, L.; Quan-Haase, A. The SAGE Handbook of Social Media Research Methods; SAGE Publications Ltd.: London, UK, 2016; ISBN 9781473916326.

63. Barnes, J.A. Class and Committees in a Norwegian Island Parish. Hum. Relat. 1954, 7, 39-58. [CrossRef]

64. Tichy, N.M.; Tushman, M.L.; Fombrun, C. Social Network Analysis For Organizations. Acad. Manag. Rev. 1979, 4, 507-519. [CrossRef]

65. Coiera, E. Social Networks, Social Media, and Social Diseases. BMJ 2013, 346, f3007. [CrossRef] [PubMed]

66. Serrat, O. Social Network Analysis. In Knowledge Solutions; Springer: Singapore, 2017; pp. 39-43. 
67. Hansen, D.L.; Shneiderman, B.; Smith, M.A.; Himelboim, I. Introduction to social media and social networks. In Analyzing Social Media Networks with NodeXL; Elsevier: Amsterdam, The Netherlands, 2020; pp. 3-10.

68. Zeng, D.; Chen, H.; Lusch, R.; Li, S.-H. Social Media Analytics and Intelligence. IEEE Intell. Syst. 2010, 25, 13-16. [CrossRef]

69. Stieglitz, S.; Dang-Xuan, L.; Bruns, A.; Neuberger, C. Social Media Analytics. Wirtschaftsinformatik 2014, 56, 101-109. [CrossRef]

70. Callau, A.À.; Albert, M.Y.P.; Rota, J.J.; Giné, D.S. Landscape Characterization Using Photographs from Crowdsourced Platforms: Content Analysis of Social Media Photographs. Open Geosci. 2019, 11, 558-571. [CrossRef]

71. Richards, D.R.; Friess, D.A. A Rapid Indicator of Cultural Ecosystem Service Usage at a Fine Spatial Scale: Content Analysis of Social Media Photographs. Ecol. Indic. 2015, 53, 187-195. [CrossRef]

72. Xiao, Y.; Huang, Q.; Wu, K. Understanding Social Media Data for Disaster Management. Nat. Hazards 2015, 79, 1663-1679. [CrossRef]

73. Zhang, Z.; He, Q.; Gao, J.; Ni, M. A Deep Learning Approach for Detecting Traffic Accidents from Social Media Data. Transp. Res. Part C Emerg. Technol. 2018, 86, 580-596. [CrossRef]

74. Yusof, N.F.A.; Lin, C.; He, Y. Sentiment Analysis in Social Media. In Encyclopedia of Social Network Analysis and Mining; Springer: New York, NY, USA, 2018; pp. 2386-2399.

75. Nemes, L.; Kiss, A. Social Media Sentiment Analysis Based on COVID-19. J. Inf. Telecommun. 2021, 5, 1-15. [CrossRef]

76. Kang, Y.; Wang, Y.; Zhang, D.; Zhou, L. The Public's Opinions on a New School Meals Policy for Childhood Obesity Prevention in the U.S.: A Social Media Analytics Approach. Int. J. Med. Inform. 2017, 103, 83-88. [CrossRef]

77. Qiu, J.; Lin, Z.; Shuai, Q. Investigating the Opinions Distribution in the Controversy on Social Media. Inf. Sci. 2019, 489, 274-288. [CrossRef]

78. Vaughan, L. Web Hyperlink Analysis. In Encyclopedia of Social Measurement; Elsevier: Amsterdam, The Netherlands, 2005; pp. 949-954.

79. Pallavicini, F.; Cipresso, P.; Mantovani, F. Beyond Sentiment. In Sentiment Analysis in Social Networks; Elsevier: Amsterdam, The Netherlands, 2017; pp. 13-29.

80. Perez, C.; Germon, R. Graph Creation and Analysis for Linking Actors: Application to Social Data. In Automating Open Source Intelligence; Elsevier: Amsterdam, The Netherlands, 2016; pp. 103-129.

81. Himelboim, I. Social Network Analysis (Social Media). In The International Encyclopedia of Communication Research Methods; Wiley: Hoboken, NJ, USA, 2017; pp. 1-15.

82. Hansen, D.L.; Shneiderman, B.; Smith, M.A.; Himelboim, I. Calculating and visualizing network metrics. In Analyzing Social Media Networks with NodeXL; Elsevier: Amsterdam, The Netherlands, 2020; pp. 79-94.

83. Pilař, L.; Kvasničková Stanislavská, L.; Kvasnička, R.; Bouda, P.; Pitrová, J. Framework for Social Media Analysis Based on Hashtag Research. Appl. Sci. 2021, 11, 3697. [CrossRef]

84. Chang, H.-C.; Iyer, H. Trends in Twitter Hashtag Applications: Design Features for Value-Added Dimensions to Future Library Catalogues. Libr. Trends 2012, 61, 248-258. [CrossRef]

85. Pilař, L.; Kvasničková Stanislavská, L.; Pitrová, J.; Krejčí, I.; Tichá, I.; Chalupová, M. Twitter Analysis of Global Communication in the Field of Sustainability. Sustainability 2019, 11, 6958. [CrossRef]

86. Kvasničková Stanislavská, L.; Pilař, L.; Margarisová, K.; Kvasnička, R. Corporate Social Responsibility and Social Media: Comparison between Developing and Developed Countries. Sustainability 2020, 12, 5255. [CrossRef]

87. Pilar, L.; Moulis, P.; Pitrová, J.; Bouda, P.; Gresham, G.; Balcarová, T.; Rojík, S. Education and Business as a Key Topics at the Instagram Posts in the Area of Gamification. J. Effic. Responsib. Educ. Sci. 2019, 12, 26-33. [CrossRef]

88. Bastian, M.; Heymann, S.; Jacomy, M. Gephi: An Open Source Software for Exploring and Manipulating Networks. In Proceedings of the International AAAI Conference on Weblogs and Social Media, Menlo Park, CA, USA, 17-20 May 2009.

89. Mittal, R.; Bhatia, M.P.S. Discovering Bottlenecks Entities in Multi-Layer Social Networks. J. Discret. Math. Sci. Cryptogr. 2019, 22, 241-252. [CrossRef]

90. McCurdie, T.; Sanderson, P.; Aitken, L.M. Applying Social Network Analysis to the Examination of Interruptions in Healthcare. Appl. Ergon. 2018, 67, 50-60. [CrossRef] [PubMed]

91. Newman, M.E.J.; Girvan, M. Finding and Evaluating Community Structure in Networks. Phys. Rev. E 2004, 69, 026113. [CrossRef]

92. Knoke, D.; Yang, S. Social Network Analysis; SAGE Publications: Thousand Oaks, CA, USA, 2008; Volume 154, ISBN 9781412927499.

93. Blondel, V.D.; Guillaume, J.-L.; Lambiotte, R.; Lefebvre, E. Fast Unfolding of Communities in Large Networks. J. Stat. Mech. Theory Exp. 2008, 2008, P10008. [CrossRef]

94. Smith, A.; Shneiderman, B.; Himelboim, I. Mapping Twitter Topic Networks: From Polarized Crowds to Community Clusters. Available online: http:/ / www.pewinternet.org/2014/02/20/mapping-twitter-topic-networks-from-polarized-crowdsto-community-clusters/ (accessed on 1 April 2021).

95. Jacomy, M.; Venturini, T.; Heymann, S.; Bastian, M. ForceAtlas2, a Continuous Graph Layout Algorithm for Handy Network Visualization Designed for the Gephi Software. PLoS ONE 2014, 9, e98679. [CrossRef]

96. Wahl, D.R.; Villinger, K.; König, L.M.; Ziesemer, K.; Schupp, H.T.; Renner, B. Healthy Food Choices Are Happy Food Choices: Evidence from a Real Life Sample Using Smartphone Based Assessments. Sci. Rep. 2017, 7, 17069. [CrossRef]

97. Lea, E.; Worsley, A. Influences on Meat Consumption in Australia. Appetite 2001, 36, 127-136. [CrossRef]

98. Rosenfeld, D.L.; Burrow, A.L. The Unified Model of Vegetarian Identity: A Conceptual Framework for Understanding Plant-Based Food Choices. Appetite 2017, 112, 78-95. [CrossRef] 
99. Bresnahan, M.; Zhuang, J.; Zhu, X. Why Is the Vegan Line in the Dining Hall Always the Shortest? Understanding Vegan Stigma. Stigma Health 2016, 1, 3-15. [CrossRef]

100. Cole, M.; Morgan, K. Vegaphobia: Derogatory Discourses of Veganism and the Reproduction of Speciesism in UK National Newspapers1. Br. J. Sociol. 2011, 62, 134-153. [CrossRef] [PubMed]

101. Wright, L. The Vegan Studies Project: Food, Animals, and Gender in the Age of Terror; University of Georgia Press: Athens, GA, USA, 2015; ISBN 0820348562.

102. Markowski, K.L.; Roxburgh, S. "If I Became a Vegan, My Family and Friends Would Hate Me:" Anticipating Vegan Stigma as a Barrier to Plant-Based Diets. Appetite 2019, 135, 1-9. [CrossRef] [PubMed]

103. Saari, U.A.; Herstatt, C.; Tiwari, R.; Dedehayir, O.; Mäkinen, S.J. The Vegan Trend and the Microfoundations of Institutional Change: A Commentary on Food Producers' Sustainable Innovation Journeys in Europe. Trends Food Sci. Technol. 2021, 107, 161-167. [CrossRef]

104. Harrington, S.; Collis, C.; Dedehayir, O. It's Not (Just) about the f-Ckin'animals: How Veganism Is Changing, and Why That Matters. In Alternative Food Politics: From Margins to Mainstream; Taylor \& Francis Group: Milton, UK; Abingdon, UK, 2019; pp. 135-150.

105. Banis, D. Everything Is Ready To Make 2019 The “Year Of The Vegan”. Are you? Available online: https://www.forbes.com/ sites / davidebanis / 2018/12/31/everything-is-ready-to-make-2019-the-year-of-the-vegan-are-you/?sh=4e56148e57df (accessed on 1 April 2021).

106. Couch, S.C.; Glanz, K.; Zhou, C.; Sallis, J.F.; Saelens, B.E. Home Food Environment in Relation to Children's Diet Quality and Weight Status. J. Acad. Nutr. Diet. 2014, 114, 1569-1579.e1. [CrossRef]

107. Smith, A. Clean Eating's Surprising Normalisation: The Case of Nigella Lawson. Discourse Context Media 2020, $35,100376$. [CrossRef]

108. Allen, M.; Dickinson, K.; Prichard, I. The Dirt on Clean Eating: A Cross Sectional Analysis of Dietary Intake, Restrained Eating and Opinions about Clean Eating among Women. Nutrients 2018, 10, 1266. [CrossRef]

109. Ambwani, S.; Sellinger, G.; Rose, K.L.; Richmond, T.K.; Sonneville, K.R. "It's Healthy Because It's Natural." Perceptions of "Clean" Eating among U.S. Adolescents and Emerging Adults. Nutrients 2020, 12, 1708. [CrossRef] [PubMed]

110. Ramage, S.; Farmer, A.; Eccles, K.A.; McCargar, L. Healthy Strategies for Successful Weight Loss and Weight Maintenance: A Systematic Review. Appl. Physiol. Nutr. Metab. 2014, 39, 1-20. [CrossRef] [PubMed]

111. Cava, E.; Yeat, N.C.; Mittendorfer, B. Preserving Healthy Muscle during Weight Loss. Adv. Nutr. 2017, 8, 511-519. [CrossRef] [PubMed]

112. Finucane, M.M.; Stevens, G.A.; Cowan, M.J.; Danaei, G.; Lin, J.K.; Paciorek, C.J.; Singh, G.M.; Gutierrez, H.R.; Lu, Y.; Bahalim, A.N.; et al. National, Regional, and Global Trends in Body-Mass Index since 1980: Systematic Analysis of Health Examination Surveys and Epidemiological Studies with 960 Country-Years and 9.1 Million Participants. Lancet 2011, 377, 557-567. [CrossRef]

113. Revels, S.; Kumar, S.A.P.; Ben-Assuli, O. Predicting Obesity Rate and Obesity-Related Healthcare Costs Using Data Analytics. Health Policy Technol. 2017, 6, 198-207. [CrossRef]

114. Frank, A.P.; de Souza Santos, R.; Palmer, B.F.; Clegg, D.J. Determinants of Body Fat Distribution in Humans May Provide Insight about Obesity-Related Health Risks. J. Lipid Res. 2019, 60, 1710-1719. [CrossRef] [PubMed]

115. Formica, V.; Morelli, C.; Riondino, S.; Renzi, N.; Nitti, D.; Di Daniele, N.; Roselli, M.; Tesauro, M. Obesity and Common Pathways of Cancer and Cardiovascular Disease. Endocr. Metab. Sci. 2020, 1, 100065. [CrossRef]

116. Le Brocq, S.; Clare, K.; Bryant, M.; Roberts, K.; Tahrani, A. Obesity and COVID-19: A Call for Action from People Living with Obesity. Lancet Diabetes Endocrinol. 2020, 8, 652-654. [CrossRef]

117. Lee, H.; Choi, E.-K.; Lee, S.-H.; Han, K.-D.; Rhee, T.-M.; Park, C.-S.; Lee, S.-R.; Choe, W.-S.; Lim, W.-H.; Kang, S.-H.; et al. Atrial Fibrillation Risk in Metabolically Healthy Obesity: A Nationwide Population-Based Study. Int. J. Cardiol. 2017, 240, 221-227. [CrossRef]

118. Tiggemann, M.; Slater, A. NetTweens: The Internet and Body Image Concerns in Preteenage Girls. J. Early Adolesc. 2014, 34, 606-620. [CrossRef]

119. Meier, E.P.; Gray, J. Facebook Photo Activity Associated with Body Image Disturbance in Adolescent Girls. Cyberpsychol. Behav. Soc. Netw. 2014, 17, 199-206. [CrossRef] [PubMed]

120. Sidani, J.E.; Shensa, A.; Hoffman, B.; Hanmer, J.; Primack, B.A. The Association between Social Media Use and Eating Concerns among US Young Adults. J. Acad. Nutr. Diet. 2016, 116, 1465-1472. [CrossRef] [PubMed]

121. Saul, J.S.; Rodgers, R.F. Adolescent Eating Disorder Risk and the Online World. Child Adolesc. Psychiatr. Clin. N. Am. 2018, 27, 221-228. [CrossRef] [PubMed]

122. Arseniev-Koehler, A.; Lee, H.; McCormick, T.; Moreno, M.A. \#Proana: Pro-Eating Disorder Socialization on Twitter. J. Adolesc. Health 2016, 58, 659-664. [CrossRef] [PubMed]

123. Muralidhara, S.; Paul, M.J. \#Healthy Selfies: Exploration of Health Topics on Instagram. JMIR Public Health Surveill. 2018, 4, e10150. [CrossRef]

124. Cavazza, N.; Graziani, A.R.; Guidetti, M. Impression Formation via \#foodporn: Effects of Posting Gender-Stereotyped Food Pictures on Instagram Profiles. Appetite 2020, 147, 104565. [CrossRef]

125. Ventura, V.; Cavaliere, A.; Iannò, B. \#Socialfood: Virtuous or Vicious? A Systematic Review. Trends Food Sci. Technol. 2021, 110, 674-686. [CrossRef] 
126. Mejova, Y.; Haddadi, H.; Noulas, A.; Weber, I. \#FoodPorn. In Proceedings of the 5th International Conference on Digital Health 2015-DH '15, Florence, Italy, 18-20 May 2015; pp. 51-58.

127. Mejova, Y.; Abbar, S.; Haddadi, H. Fetishizing Food in Digital Age: \#food Porn around the World. In Proceedings of the 10th International AAAI Conference on Web and Social Media (ICWSM 2016), Cologne, Germany, 17-20 May 2016.

128. Hessel, J.; Chenhao, T.; Lee, L. Science, AskScience and BadScience: On the Coexistence of Highly Related Communities. In Proceedings of the 10th International AAAI Conference on Web and Social Media, Cologne, Germany, 17-20 May 2016.

129. Coates, A.E.; Hardman, C.A.; Halford, J.C.G.; Christiansen, P.; Boyland, E.J. Social Media Influencer Marketing and Children's Food Intake: A Randomized Trial. Pediatrics 2019, 143, e20182554. [CrossRef]

130. Littlejohns, T.J.; Chong, A.Y.; Allen, N.E.; Arnold, M.; Bradbury, K.E.; Mentzer, A.J.; Soilleux, E.J.; Carter, J.L. Genetic, Lifestyle, and Health-Related Characteristics of Adults without Celiac Disease Who Follow a Gluten-Free Diet: A Population-Based Study of 124,447 Participants. Am. J. Clin. Nutr. 2021, 113, 622-629. [CrossRef]

131. Silvester, J.A.; Weiten, D.; Graff, L.A.; Walker, J.R.; Duerksen, D.R. Living Gluten-Free: Adherence, Knowledge, Lifestyle Adaptations and Feelings towards a Gluten-Free Diet. J. Hum. Nutr. Diet. 2016, 29, 374-382. [CrossRef]

132. Niland, B.; Cash, B.D. Health Benefits and Adverse Effects of a Gluten-Free Diet in Non-Celiac Disease Patients. Gastroenterol. Hepatol. 2018, 14, 82-91.

133. Parra-Fernández, M.L.; Manzaneque-Cañadillas, M.; Onieva-Zafra, M.D.; Fernández-Martínez, E.; Fernández-Muñoz, J.J.; PradoLaguna, M.D.C.; Brytek-Matera, A. Pathological Preoccupation with Healthy Eating (Orthorexia Nervosa) in a Spanish Sample with Vegetarian, Vegan, and Non-Vegetarian Dietary Patterns. Nutrients 2020, 12, 3907. [CrossRef] [PubMed]

134. Strahler, J. The Dark Side of Healthy Eating: Links between Orthorexic Eating and Mental Health. Nutrients 2020, $12,3662$. [CrossRef] [PubMed]

135. Brytek-Matera, A.; Onieva-Zafra, M.D.; Parra-Fernández, M.L.; Staniszewska, A.; Modrzejewska, J.; Fernández-Martínez, E. Evaluation of Orthorexia Nervosa and Symptomatology Associated with Eating Disorders among European University Students: A Multicentre Cross-Sectional Study. Nutrients 2020, 12, 3716. [CrossRef] [PubMed]

136. Turner, P.G.; Lefevre, C.E. Instagram Use Is Linked to Increased Symptoms of Orthorexia Nervosa. Eat. Weight Disord. 2017, 22, 277-284. [CrossRef]

137. Bostock, E.C.S.; Kirkby, K.C.; Taylor, B.V.; Hawrelak, J.A. Consumer Reports of "Keto Flu" Associated With the Ketogenic Diet. Front. Nutr. 2020, 7. [CrossRef] [PubMed]

138. Caprio, M.; Infante, M.; Moriconi, E.; Armani, A.; Fabbri, A.; Mantovani, G.; Mariani, S.; Lubrano, C.; Poggiogalle, E.; Migliaccio, S.; et al. Very-Low-Calorie Ketogenic Diet (VLCKD) in the Management of Metabolic Diseases: Systematic Review and Consensus Statement from the Italian Society of Endocrinology (SIE). J. Endocrinol. Investig. 2019, 42, 1365-1386. [CrossRef] [PubMed]

139. Siegel, B.I.; Johnson, M.; Dawson, T.E.; Kurzen, E.; Holt, P.J.; Wolf, D.S.; Orenstein, E.W. Reducing Prescribing Errors in Hospitalized Children on the Ketogenic Diet. Pediatr. Neurol. 2021, 115, 42-47. [CrossRef]

140. Pittman, Q.J. A Gut Feeling about the Ketogenic Diet in Epilepsy. Epilepsy Res. 2020, 166, 106409. [CrossRef]

141. Mohorko, N.; Černelič-Bizjak, M.; Poklar-Vatovec, T.; Grom, G.; Kenig, S.; Petelin, A.; Jenko-Pražnikar, Z. Weight Loss, Improved Physical Performance, Cognitive Function, Eating Behavior, and Metabolic Profile in a 12-Week Ketogenic Diet in Obese Adults. Nutr. Res. 2019, 62, 64-77. [CrossRef]

142. Xiong, Y.; Cho, M.; Boatwright, B. Hashtag Activism and Message Frames among Social Movement Organizations: Semantic Network Analysis and Thematic Analysis of Twitter during the \#MeToo Movement. Public Relat. Rev. 2019, 45, 10-23. [CrossRef]

143. Giroux, N.F. The Keto Diet and Long-Term Weight Loss: Is It a Safe Option? Inq. J. 2020, 12, 1. 